\section{Klokt om kronisk sykdom}

\author{
Elin Fjerstad
}

Frisk og kronisk syk

Et psykologisk perspektiv på kronisk sykdom. 297 s, tab, ill. Oslo: Gyldendal Akademisk, 2010. Pris NOK 349

ISBN 978-82-05-40235-5

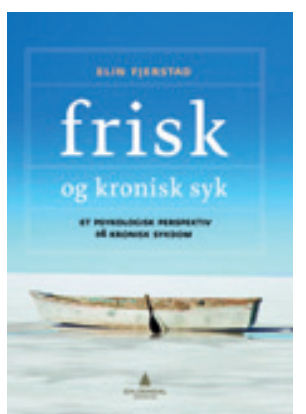

Målgruppen er alle helsearbeidere som møter pasienter med kronisk sykdom, og studenter innenfor helsefag som psykologi, medisin, sykepleie, ergoterapi og fysioterapi. Boken er også en lærebok

for de som selv er kronisk syke, og for deres pårørende. Forfatteren, som er psykolog, har omfattende erfaring, både personlig og klinisk, med behandling av kronisk revmatologisk sykdom. Overføringsverdien til annen kronisk sykdom er stor.

Tittelen, Frisk og kronisk syk, understreker at kronisk sykdom ikke må løsrives fra den friske personen som har sykdommen. Kronisk sykdom innebærer derfor å være både syk og frisk, ikke enten syk eller frisk.

Forfatteren formidler kunnskap om hvordan det er å ha en sykdom som aldri går over, og hvordan man kan leve best mulig med de utfordringene dette innebærer.

Innledningsvis handler det om forskning og teori knyttet til det å leve med kronisk sykdom, og deretter presenterer forfatteren teori og forskning omkring mestring. Herunder omtaler hun sentrale bidrag fra utviklingspsykologi, familieteori, helsepsykologi, positiv psykologi og kognitiv psykologi. Etter en oversikt over hva mestring innebærer, omtaler hun hva som skal mestres ved kronisk revmatisk sykdom. Deretter blir smerte og hvordan sykdommens medisinske kjennetegn farger de mentale og følelsesmessige belastningene, omtalt. Kronisk sykdom som krise, at tilvenning til et liv som kronisk syk innebærer at sykdommen må aksepteres, og at selvfølelsen på ulike måter berøres, og at psykiske reaksjoner kommer i forløpet av kronisk sykdom, blir også behandlet på en klok måte.

Den siste delen handler om god helse ved kronisk sykdom. Her gjennomgår Fjerstad kognitiv terapi ved kronisk sykdom og de terapeutiske mulighetene dette innebærer. Målet med kognitiv terapi er å få økt forståelse av hvordan mental aktivitet virker inn på hvordan man har det med seg selv, med andre, med sykdommen og med fremtiden. Det er et verktøy for å håndtere reaksjoner på å få en kronisk sykdom, for tilpasning til den og for å forebygge utvikling av angst og depresjon. Kunsten er ikke å være prisgitt sine egne tanker, men å velge hvilke tanker man skal bry seg om, og hvilke man skal la fare. Avslutningsvis diskuterer forfatteren medikamentavhengighet og forebygging av misbruk av opiater.

Den store pedagogiske styrken er at man gjennomgående presenterer konkrete eksempler på hvordan man kan samtale med barn og voksne om ulike sider ved det å ha kronisk sykdom.

Et stort tilfang på relevant litteratur er integrert i forhold til lett gjenkjennlige kliniske situasjoner og utfordringer på en uvanlig god måte.

Jeg anbefaler boken både for praktiserende leger og som pensumslitteratur for medisinstudenter.

\section{Tore Sørlie}

Institutt for klinisk medisin

Det helsevitenskapelige fakultet

Universitetet i Troms $\varnothing$

\section{Åpent, men skjult}

Anna Tostrup Worsley

\section{Kronisk}

253 s. Oslo: Unipub, 2010. Pris NOK 349

ISBN 978-82-7477-478-0

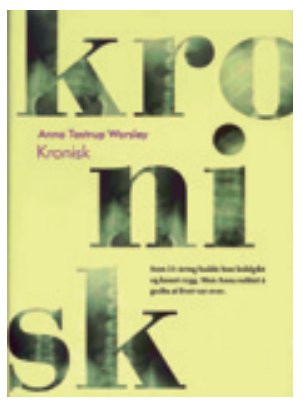

Denne boken er et oppgjør med helsevesenets menneskesyn og måte å møte og behandle mennesker på. Den er også et forsøk på å riste av seg pasientrollen og uførhetsstemplet.

Boken er skrevet av en ung kvinne som omtaler seg selv som mangeårig trofast bruker av norsk helsetjeneste, og som politisk og økonomisk helseflyktning, nå bosatt i Sverige. Den er interessant og utfordrende når det gjelder forfatterens nær sagt uforbeholdne åpenhet angående egen sykdom. Likevel fornemmer man også en annen historie som forblir tilnærmet skjult.

Hva er åpent? Anklagen - i form av en ordrik, kronologisk fortalt sykdomshistorie fra å ha vært: «en veldig frisk jente; nesten aldri forkjøla, alltid sterk og sunn; som spilte fotball med gutta, klatret i trær, danset ballett, red på islandshest, smidde kniver, tegnet, malte, løp i skogen med hunden» til å ha blitt: «29 år gammel, skilt, uføretrygdet og nylig unnsluppet fra psykiatrisk avdeling; ikke akkurat en samfunnsvinner.»

Hva er skjult? Klagen - i form av en ordknapp, spredt og bare antydet traumeog tapshistorie som favner hentydninger til en brann, foreldrenes første separasjon og senere skilsmisse, og til en voldtekt i ungdomstiden, og beskrivelser av utleverthet til en seksualiserende og foraktelig lege, gjentatt umyndiggjøring i hjelpens navn, skader som følge av medisinske grep, en tvangsinnleggelse, et møte med en brannstifter, avbrutte studier, en skilsmisse, hjemløshet, uførhet og avhengighet.

Hva forbinder den åpne og den skjulte historien? Kroppen - en ung kvinnes levde kropp, den som har, ifølge ørsmå antydninger, en belastet oppvekst i seg, hvor skader og brudd, i konkret og overført betydning, fortløpende både innskrives og reaktiveres.

Skadene er dels åpenbare, navngitt i medisinfagets diagnostiske termer (senebetennelse, revmatoid artritt, multiple frakturer, nakkesleng) eller betinget av helsefagenes ulike tiltak (kortison- og cellegiftbehandling, gjentatte operasjoner, vanedannende medisiner, eksperimenterende behandling, passivisering, tvangsinnleggelse, umyndiggjøring).

Skadene er dels tildekket av vage omskrivninger. Hva de handler om, antydes bare med noen få, spredte og dels tvetydige ord. Noen av dem er også tildekket ved å være kodet i ordrike fortellinger over et grunnleggende mønster: Enhver opplevelse av å være prisgitt andres kontroll, og enda verre, andres antatte eller åpenbare vilkårlighet, utløser flukt.

På en underlig og samtidig logisk måte bidrar skadene, bruddene og avmakten til at skilte foreldre sammen blir både flukthjelpere og formyndere for sin voksne datter, som velger juridisk sikret umyndighet som vern mot flere inn- eller overgrep fra helse- 
vesenet. Og på en like underlig og logisk måte dokumenterer denne boken hvor destruktivt det er at inkorporert avmaktserfaring som regel ikke blir et sentralt tema i medisinske møter. Derfor innebærer boken et budskap til alle leger: Ingen menneskekropp kan betraktes, vurderes eller behandles som om den var erfarings- og historieløs. Men den innebærer også et budskap til alle pasienter: All vond og vanskelig erfaring som holdes eller forblir skjult, nærer smerte, angst og sykdom og gjør selv gode hjelpere avmektige.

\section{Anna Luise Kirkengen}

Senter for helsefremmende arbeid

Akershus universitetssykehus

\section{Etter diagnosen}

Julian Seifter

After the diagnosis

Transcending chronic illness. 243 s. New York, NY: Simon \& Schuster, 2010. Pris USD 25

ISBN 978-1-4391-2304-1

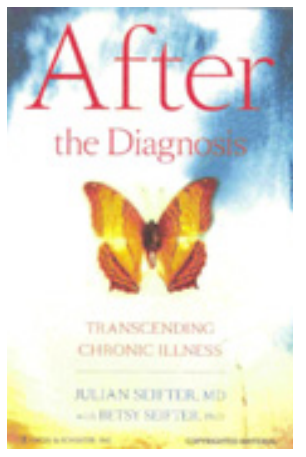

Forfatteren er nefrolog og lærer ved Harvard Medical School i Boston. Med denne boken ønsker han å belyse måter å se på, behandle og forstå pasienter som får diagnostisert en kronisk sykdom. I hvert av de ni kapitlene tar han for seg forskjellige mestringsstrategier som hans pasienter har brukt for å leve med sin kroniske sykdom.

Hvert kapittel begynner med en kort pasienthistorie. Seifter beskriver der sitt møte med forskjellige mennesketyper som har fătt diagnostisert en kronisk sykdom hvordan de tar den første beskjeden, og hvordan de så lærer å håndtere sin situasjon på forskjellige måter. Historiene fremhever på en meget fin måte at pasientene ikke er en samling tegn og symptomer, men at de er individer med personlighet og historier. Han får frem at et godt lege-pasient-forhold må ta høyde for og bruke tid på å se og forstå hele personen - også deres negative og følelsesmessige sider. Av og til må man glemme eksisterende regler og hjelpe pasientene til å skape og etablere personlige og kreative løsninger, uavhengig av hva som er «medisinsk korrekt».

Som ung, nyutdannet og meget ambisiøs lege fikk han selv diagnosen diabetes mellitus. God personlig helse uten sykdom var en del av hans image, og det å innse at han trengte behandling ble initialt et stort nederlag. Han tolker hyppig pasientens reaksjonsmønster og sammenlikner disse med sine personlige erfaringer. Ofte er det en del refleksjoner som leseren selv må gruble over. Han påpeker og fremhever hele tiden at det å få en kronisk sykdom egentlig ikke trenger å være «noe fremmed og destruktivt», men faktisk kan være et verktøy for personlig vekst.

Hovedbudskapet er at du som pasient ikke er en diagnose. Du er du! Forfatteren skriver godt, og boken er derfor lettlest. Han bruker sine erfaringer fra et helt liv som nyrespesialist og lærer. Målgruppen er nok først og fremst helsepersonell, og da særlig leger som jobber med pasienter som får diagnostisert kroniske sykdommer, men budskapet er viktig for alle andre som jobber med, eller selv har en kronisk sykdom. Jeg fant boken interessant og engasjerende og anbefaler den til alle som ønsker å øke sin forståelse og innsikt rundt det å leve med en kronisk sykdom.

\section{Karsten Midtvedt}

Nyreseksjonen

Medisinsk klinikk

Oslo universitetssykehus, Rikshospitalet

\section{God informasjon til gravide}

Tore Henriksen

I mors liv

Svangerskap, fosterliv og helse. 239 s, ill. Oslo: Cappelen Damm, 2010. Pris NOK 369 ISBN 978-82-02-30888-9

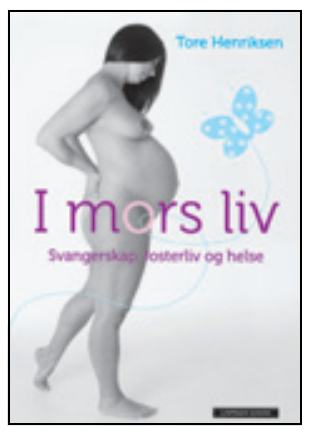

Tore Henriksen, professor og seksjonsoverlege ved Kvinneklinikken på Rikshospitalet, har skrevet en informasjonsbok til gravide kvinner og deres partnere. Boken er delt $i$ tre hovedkapitler: Fosterutviklingen,

svangerskapet og fødselen, Komplikasjoner og sykdom i svangerskapet og Komplikasjoner under og etter fødselen.

Innholdet er faglig solid, og i tillegg til tradisjonelt stoff kommer forfatteren også inn på nyere og til dels kontroversielle tema, som lagring av stamceller og muligheter for fremtidig fosterdiagnostikk ved analyse av føtalt DNA i maternelt blod. Jeg synes at de innledende kapitlene er spesielt gode. Henriksen er på hjemmebane når han skriver om celler, befruktning og tidlig fosterutvikling. En av hans hovedinteresser er ernæring, som også dekkes på en ypperlig måte. Omtalen av fysiologiske forandringer hos gravide er også velskrevet og direkte spennende, og et eksempel på fremragende formidling av komplisert fagstoff.
Boken er personlig skrevet. Forfatteren bruker ofte jeg-formen, og på denne måten får boken et visst preg av biografi. Han formidler sine erfaringer, for eksempel: «jeg har opplevd», «jeg får ikke sjelden telefoner fra», «erfaringen ellers er at», «jeg glemmer ikke». På meg virker denne skriveformen litt gammelmodig og kanskje litt patriarkalsk, det skal noe til for at egne erfaringer blir allmenngyldige. Forfatteren taler også til leseren i duform, for eksempel: «du skal kose deg med maten», «hvis du mener det er blitt mindre bevegelser, skal du». Det er igjen kanskje en smakssak, men den som leser uten selv å være gravid, kan lett føle seg fremmedgjort.

Liberal bruk av «såkalt» er en felle som mange fagfolk går i når de skal popularisere fagstoff. To eksempler: «Da tar vi i bruk såkalt CTG-registrering», «såkalt cerclage (uttales «særklasj»)». Ordet «såkalt» gir ingen mening i slike sammenhenger. CTG er ikke såkalt CTG og cerclage er også hva det er - en tråd som er sydd rundt livmorhalsen. Fremmede eller vanskelige ord blir ikke lettere forståelige hvis man skriver såkalt foran, snarere tvert om. Som leser lurer man på hva det egentlig skulle hete.

Det er en rekke flotte bilder, av slanke, gravide kvinner med perfekte kropper. Min lille innvending er at kanskje ikke alle i målgruppen vil kjenne seg igjen.

Forfatteren gir en faglig stødig, oppdatert og omfattende gjennomgang av svangerskap, fødsel og nyfødtperiode, med vekt på å forklare hva som skjer fysiologisk. Dette er en god informasjonsbok som jeg trygt kan anbefale til gravide og deres partnere.

\section{Bjørn Backe}

Kvinneklinikken

St. Olavs hospital

\section{Ikke tier om tinnitus}

Peter B. Paaske

\section{Doktor, hvorfor har jeg tin9tus?}

Her får du en forklaring på hele høresystemet. 123 s, ill. Århus: Peter B. Paaske, 2010.

Pris DKK 159

ISBN 978-87-993644-0-4

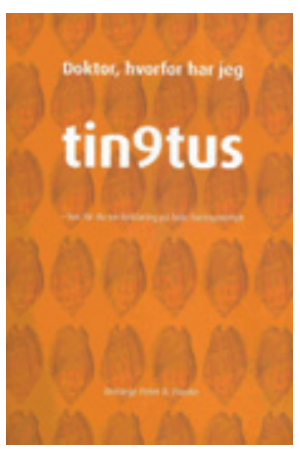

Forfatteren, som er praktiserende øre-nese-halsspesialist, har på eget forlag gitt ut en personlig preget bok om øresus, rettet mot pasienten med øresus og pårørende. $\AA$ hevde at målgruppen er helsepersonell som arbeider med hørsel og øresus, er å gå for langt; til det er presisjonsnivået for lavt. 